\title{
Color Removal in Textile Wastewaters using Natural Adsorbents as a Sustainable way of Treatment
}

\author{
Wojciech Stawiński1 ${ }^{1}$, Sónia Figueiredo ${ }^{1}$, Agnieszka Węgrzynn², Olga Freitas ${ }^{1 *}$ \\ ${ }^{1}$ REQUIMTE/LAQV, Instituto Superior de Engenharia do Porto, Rua Dr. António Bernardino de Almeida 431, 4200-072 Porto, Portugal \\ ${ }^{2}$ Faculty of Chemistry, Jagiellonian University, Kraków, Poland
}

Submission: January 16, 2018; Published: February 06, 2018

*Corresponding author: Olga Freitas, REQUIMTE/LAQV, Instituto Superior de Engenharia do Porto, Rua Dr. António Bernardino de Almeida 431 , 4200-072 Porto, Portugal, Email: omf@isep.ipp.pt

\section{Introduction}

Water plays a vital role in the proper functioning of the Earth's ecosystem and at the same time it is the most exploited natural resource, which is limited. Sustainable treatment of wastewaters and recycling methods are important issues for getting fresh water in the coming decades [1].

Consumption of textiles is the largest end-use market for dyestuffs [2] leading to high consumption of dyes. The conventional secondary wastewater treatments applied to textile effluents are not efficient for color removal therefore dyestuffs will enter in the aquatic environment. They may cause adverse acute or chronic effects on all forms of life [3]. The presence of dyes in the aquatic environment reduces the absorption of sunlight and consequently the photosynthetic activity. Also the public perception of water quality is greatly influenced by color, which is visible even for very low concentrations [4].

There are various tertiary water treatment methods however some of them are economically challenging [1]. The adsorption process has been proven to be one of the most promising approach for water treatment [1] due to its low cost and ease to implement. The most used commercial adsorbent is activated carbon. The search for more economic alternative adsorbents leads to the study of natural materials.

A huge variety of natural low cost adsorbents, such as clay minerals, layered double hydroxides, feathers, shells and pens, have been proven to act efficiently in removal of textile dyestuffs.

\section{Color removal by low-cost natural adsorbents}

Clay minerals are known to be good adsorbents for cationic dyes. Stawiński, et al. [5] developed an efficient adsorbent by acid activation of a clay mineral, vermiculite, using nitric and citric acid. Later on the same author [6] found out that the performance of such prepared material can be significantly enhanced when an additional step comprising rinsing in diluted $\mathrm{NaOH}$ is added to the treatment. Finally the developed adsorbents were tested in multi component system and in constant flow column systems [7] providing evidence of their high efficiency and possibility of regeneration and reuse. A hydrotalcite-based material capable of removing anionic dyes for wastewater was tested by Stawiński, et al. [8]. Its adsorption capacity was significantly increased by thermal treatment, which allows also the regeneration of the spent adsorbent.

Table_1: Results of adsorption experiments of textile dyes onto natural adsorbents (the maximum adsorption capacities are based on Langmuir's model adjustment).

\begin{tabular}{|c|c|c|c|}
\hline Material & \multicolumn{2}{|c|}{ Capacity $\left(\mathrm{mg} \mathrm{g}^{-1}\right)$} & Reference \\
\hline & CI Basic Red 46 & CI Basic Blue 9 & \multirow{2}{*}{ [6] } \\
\hline \multirow[t]{2}{*}{$\mathrm{NaOH}$ modified vermiculite } & $155 \pm 11$ & $161 \pm 5$ & \\
\hline & CI Basic Red 46 & Reactive dye* & \multirow{2}{*}{ [8] } \\
\hline Hydrotalcite & $4.8 \pm 0.3$ & $179 \pm 5$ & \\
\hline \multirow[t]{2}{*}{ Thermally modified hydrotalcite } & $31 \pm 5$ & $291 \pm 8$ & \\
\hline & CI Basic Red 46 & CI Basic Blue 9 & \multirow{3}{*}{ [5] } \\
\hline Vermiculite & $44 \pm 1$ & $53 \pm 10$ & \\
\hline $\begin{array}{l}\text { Nitric/citric acid modified } \\
\text { vermiculite }\end{array}$ & $60 \pm 2$ & $66 \pm 3$ & \\
\hline
\end{tabular}




\section{Current Trends in Fashion Technology \& Textile Engineering}

\begin{tabular}{|c|c|c|c|}
\hline & \multicolumn{2}{|c|}{ CI Reactive Yellow 39** } & \multirow{3}{*}{$\begin{array}{r}{[10]} \\
{[9]}\end{array}$} \\
\hline $\begin{array}{l}\text { Gallinaceous feathers (Gallus } \\
\text { gallus, Cobb 500) }\end{array}$ & \multicolumn{2}{|c|}{300} & \\
\hline \multirow[t]{2}{*}{ Gallinaceous feathers strain Label } & \multicolumn{2}{|c|}{200} & \\
\hline & \multicolumn{2}{|c|}{ 45-55\% CI Basic Green 4 and 35-40\% CI Basic Red 14** } & \\
\hline \multirow[t]{2}{*}{ Gallinaceous feathers } & \multicolumn{2}{|c|}{$47 \pm 8$} & [11] \\
\hline & \multicolumn{2}{|c|}{ CI Reactive Blue $220^{* *}$} & \\
\hline \multirow[t]{2}{*}{$\begin{array}{l}\text { Eucalyptus bark (from Eucalyptus } \\
\text { globulus) }\end{array}$} & \multicolumn{2}{|c|}{$90^{* * *}$} & [12] \\
\hline & CI Reactive green 12 & CI Direct green 26 & \multirow{7}{*}{$\begin{array}{l}{[13]} \\
{[14]}\end{array}$} \\
\hline Anodonta cygnea shell & $0.4 \pm 0.1$ & 11.3 & \\
\hline Sepia officinalis pen & $3.5 \pm 0.4$ & 56 & \\
\hline Loligo vulgaris pen & $44 \pm 27$ & $5 \pm 1$ & \\
\hline $\begin{array}{l}\text { Anodonta cygnea shell } \\
\text { demineralised in } \mathrm{HCl}\end{array}$ & $34 \pm 6$ & $\cdots$ & \\
\hline $\begin{array}{l}\text { Sepia officinalis pen demineralised } \\
\text { in } \mathrm{HCl}\end{array}$ & $120 \pm 3$ & $\cdots$ & \\
\hline $\begin{array}{l}\text { Loligo vulgaris pen deproteined } \\
\text { in } \mathrm{NaOH}\end{array}$ & $270 \pm 40$ & $37 \pm 9$ & \\
\hline
\end{tabular}

*Levafix Amber CA from Dystar, unknown Cl; **simulated textile effluent; ***best value recorded in this study.

Adsorption of dyes onto feathers of gallinaceous was extensively studied by Figueiredo \& Freitas [9] and Freitas, et al. [10] that investigated adsorption kinetics and equilibrium of the adsorption and Sousa, et al. [11] extended this search to adsorption experiments in fixed-bed column. Eucalyptus bark (from Eucalyptus globulus) has demonstrated also relatively good potential for color removal [12]. Also natural waste materials containing chitin (Anodonta cygnea shell and Sepia officinalis and Loligo vulgaris pens) were tested in batch and continuous (packed column) system for removal of textile dyes by Figueiredo, et al. [13], Figueiredo, et al. [14]. The detailed results of the investigations described above are presented in (Table 1), where it is shown the applicability of natural materials to adsorb several classes of dyestuffs with different charges, anionic (e.g. reactive and direct) and cationic (basic) dyes.

\section{Conclusion}

Natural low-cost materials, some of them waste products, can be successfully applied for removal of dyes from industrial wastewaters. The adsorption capacities are satisfactory and removal efficiency is good, moreover they may be enhanced on a way of various modifications of the materials. Some of the adsorbents may be subjected to simple regeneration process and reused. The utilization of natural materials offers promising perspectives for their use as alternatives to activated carbon. In the cases when natural materials are also wastes their use as adsorbents is also a way for their valorization. These studies contribute to the economical and sustainable treatment of textile effluents.

\section{References}

1. Gupta VK, Ali I (2012) Environmental Water: Advances in Treatment, Remediation and Recycling. Elsevier.

2. Markit IHS (2014) https://www.ihs.com/products/dyes-chemicaleconomics-handbook.html.

3. Hunger K (2007) Industrial Dyes: Chemistry, Properties, Applications, Wiley.

4. Gürses A, Açıkyıldız M, Güneș K, Gürses MS (2016) Dyes and Pigments. Springer International Publishing.

5. Stawiński W, Freitas O, Chmielarz L, Węgrzyn A, Komędera K, et al. (2016) Chemosphere 153: 115-129.

6. Stawiński W, Węgrzyn A, Dańko T, Freitas O, Figueiredo S, et al. (2017) Chemosphere 173: 107-115.

7. Stawiński W, Węgrzyn A, Freitas O, Chmielarz L, Mordarski G, et al. (2017) Sci Total Environ 576: 398-408.

8. Stawiński W, Węgrzyn A, Freitas O, Chmielarz L, Figueiredo S (2017) Microporous Mesoporous Mater 250: 72-87.

9. Figueiredo SA, Freitas OM (2013) Environmental Engineering and Management Journal 12: 2061-2070.

10. Freitas OM, Moura LM, Figueiredo SA, Pessoa de Amorim MT (2016) Color Technol 132: 421-430.

11. Sousa J, Freitas OM, Figueiredo SA (2012) Global Nest Journal 14: 100107.

12. Morais LC, Freitas OM, Gonçalves EP, Vasconcelos LT, González Beça CG (1999) Water Res 33: 979-988.

13. Figueiredo SA, Loureiro JM, Boaventura RA (2005) Water Res 39: 4142-4152.

14. Figueiredo SA, Boaventura RA, Loureiro JM (2000) Sep Purif Technol 20: $129-141$. 
CC (i) This work is licensed under Creative

Commons Attribution 4.0 Licens

5025598

\section{Your next submission with Juniper Publishers} will reach you the below assets

- Quality Editorial service

- Swift Peer Review

- Reprints availability

- E-prints Service

- Manuscript Podcast for convenient understanding

- Global attainment for your research

- Manuscript accessibility in different formats

( Pdf, E-pub, Full Text, Audio)

- Unceasing customer service

Track the below URL for one-step submission https://juniperpublishers.com/online-submission.php 